\title{
CONCEPTUAL FOUNDATIONS OF EMOTIONAL INTELLIGENCE AS A FACTOR IN PROFESSIONAL SELF-DETERMINATION OF HIGH SCHOOL STUDENTS
}

УДК 159.923.35

DOI https://doi.org/10.32843/2663-

5208.2020.13-2.27

\section{Шевченко С.В.}

к.психол.н., доцент кафедри психології Мелітопольський державний

педагогічний університет

імені Богдана Хмельницького

Гузь Н.В.

к.психол.н., доцент кафедри психології

Мелітопольський державний

педагогічний університет

імені Богдана Хмельницького

Гузь В.В.

к.пед.н., доцент кафредри початкової освіти

Мелітопольський державний

педагогічний університет

імені Богдана Хмельницького

Варіна Г.Б.

старший викладач кафедри психології Мелітопольський державний педагогічний університет

імені Богдана Хмельницького
Стаття присвячена теоретичному вивченню й експериментальному дослідженню емоційного інтелекту як фрактору професійного самовизначення старшокласників. У роботі наведено декілька підходів до визначення ореномена, описано структурні компоненти та ієрархічну структуру емоційного інтелекту, погляди вітчизняних учених на основні аспекти професійного самовизначення старшокласників. У результаті аналізу теоретико-методологічного конструкту виділено складові компоненти емоційного інтелекту: самосвідомість (усвідомлення людиною свого суспільного статусу та своїх життєво важливих потреб), самоконтроль (усвідомлення й оцінювання суб'єктом своїх дій, психічних прочесів і станів), емпатія (розуміння емоційного стану, проникнення-співчуття в переживання іншої людини), навички відносин (дії, які сформовані шляхом повторення, що характеризуються високим рівнем засвоєння), мотивація (спонукання, які визивають активність організму та особистості загалом і визначають iї направленість). За результатами емпіричного дослідження показників емоційного інтелекту старшокласників установлено, що в більшості досліджуваних переважає низький рівень емоційного інтелекту. Найменш вираженою в досліджуваних $\epsilon$ здатність до управління як власними емоційним станом, так й емоціями інших людей. Досліджувані із соціальною направленістю профресійного самовизначення дійсно мають високий рівень внутрішньоособистісного емоційного інтелекту. Особливо можна виділити схильність старшокласників соціального типу просресійного самовизначення до розпізнання емоцій інших людей, досліджувані з реалістичним типом професійного самовизначення мають низькі показники емпатії, досліджувані з вибором підприємницького типу професійного самовизначення мають низькі показники за шкалою управління своїми емоціями. Подальше дослідження проблематики орієнтовано на вивчення характеру зв'язку між складниками емоційного інтелекту і стабільністю статусу особистості в групі, у системі комунікативних, інтерактивних і перцептивних впливів.

Ключові слова: емоційний інтелект, професійне самовизначення, профресійне спря- мування, емпатія, емоційна обізнаність, самомотивація, управління емоціями, старшокласники.

The article is devoted to the theoretical study and experimental study of emotional intelligence as a factor in the professional self-determination of senior pupils. The paper presents several approaches to the definition of the phenomenon, defines the structural components and describes the hierarchical structure of emotional intelligence. Highlighted the views of domestic scientists on the main aspects of professional self-determination of high school students. Theoretical approaches formed the basis for the experimental study of the role of emotional intelligence in professional self-determination of high school students; psychodiagnostic methods were used: the method of professional self-determination by J. Goland, the emotional intelligence questionnaire D.V. Lyusina, N. Hall's method of emotional intelligence. According to the results of an empirical study of the indicators of emotional intelligence of high school students, it was established that the majority of the subjects dominated by a low level of emotional intelligence. The least pronounced in the subjects is the ability to manage both their own emotional state and the emotions of other people. According to the results of the study, we found that the subjects studied with the social orientation of professional self-determination really have a high level of intrapersonal emotional intelligence. Especially can highlight the tendency of high school students of the social type of professional self-determination in recognizing the emotions of other people. We also determined that subjects with a realistic type of professional self-determination have low rates of empathy. Researchers with a choice of entrepreneurial type of professional self-determination have low rates on the scale of managing their emotions. The authors identified promising guidelines for further research, which consist in studying the nature of the relationship between the components of emotional intelligence and the stability of the status of the individual in the group, in the system of communicative, interactive and perceptual actions.

Key words: emotional intelligence, professional self-determination, professional orientation, empathy, emotional awareness, self-motivation, emotion control, high school students.
Постановка проблеми. Соціальні зміни, які здійснюються в суспільстві на рівні глобальних процесів, більш доступні спогляданню, ніж процеси, які відбуваються у свідомості, психіці, внутрішньому стані індивіда. Одним із основних завдань навчання в закладах середньої освіти $€$ розвиток творчого мислення особистості, здатної адаптуватися до умов нового життя, самоосвіти, самоконтролю й самовдосконалення. Проте процес вибору життєвого та професійного шляху стає дуже складним для сучасної молоді, яка не готова правильно реагувати на навколишні події, керувати своїми емоціями, оцінювати особистісний потенціал, долати труднощі, викликані змінами в суспільстві. Система роботи шкільного пси- 
холога в основному орієнтована на допомогу старшокласнику в професійному самовизначенні. Але, крім того, одним із важливих завдань психологічного супроводу є розвиток емоційної сфери, емоційної культури діяльності. Емоційна готовність до професійної діяльності розглядається як усвідомлена готовність фахівця до реалізації емоційних компетенцій, необхідних для конструктивного вирішення професійних завдань [10]. У зв'язку з цим набуває актуальності дослідження фактору емоційного інтелекту в професійному самовизначенні, зокрема здатність до розуміння, управління й уміння контролювати свої емоції залежно від ситуації.

Аналіз останніх досліджень і публікацій. Дослідження впливу емоційного інтелекту на професійне самовизначення особистості, умови сучасного життя ґрунтується на загальних положеннях про професійну орієнтацію (Е. Клімов [7], М. Пряжніков [10]). Також проблема професійного самовизначення вивчалася Л. Божович, М. Гінзбургом [3], А. Мудрик [8], які вивчали ї̈ у зв'язку із життєвими перспективами особистості й плануванням майбутнього. Уведення поняття емоційного інтелекту в психологічний тезаурус сприяло інтенсивному зростанню кількості досліджень, спрямованих на операціоналізацію емоційно-інтелектуального конструкту, зазначали І. Андрєєва, О. Власова, Т. Головань [2], Дж.Д. Майер, П. Саловей. Дослідження науковців (Г. Березюк [1], Д. Гоулман [4], У. Дакс, С. Дерев'янко [5], Е. Носенко [9] та ін.) підтверджують, що успіх більшою мірою залежить від розумного володіння емоціями, тобто емоційним інтелектом. В Україні вивчення емоційного інтелекту набуло значного поштовху у зв'язку з дослідженнями О. Власової, С. Дерев'янко, В. Зарицької [6], Е. Носенко та ін. У свою чергу, це дає змогу розширити проблематику досліджень, залучити нові джерела, зіставити традиційні підходи з новітніми.

Постановка завдання. Мета роботи полягає в теоретичному обґрунтуванні й емпіричному дослідженні особливостей емоційного інтелекту як фактору професійного самовизначення старшокласників. Відповідно, завданнями роботи окреслено таке: дослідити теорію питання; визначити домінуючий тип професійного спрямування старшокласників, рівень їхнього емоційного інтелекту, здатність розуміти відносини особистості, що репрезентується в емоціях, і керувати емоційною сферою наосновіприйняття рішеньстаршокласниками.

Виклад основного матеріалу дослідження. Емоційний інтелект $€$ порівняно новим психічним феноменом, який розглядається в аспекті індивідуальних розбіжностей особистості. Термін уперше з'явився, як відмічають автори огляду стану розроблення проблеми, у дослідженнях Лоунера, Грінспана й у дисертації Пейна. Але найширшого розповсюдження ідеї вивчення емоційного інтелекту набули завдяки публікації серії монографій Д. Гоулмана, перша з яких вийшла в 90-ті роки. Вона спиралася на більш ранні теоретичні засади вивчення емоційного інтелекту, викладені в статті Дж. Саловея й П. Меєра. Монографія Д. Гоулмана «Емоційний інтелект» включає огляд більш ранньої літератури, зокрема досліджень із проблеми соціального інтелекту, наприклад, праці Торндайка, Гарднера, присвячені теорії множинності проявів інтелекту [4]. В останнє десятиліття дослідження емоційного інтелекту (EI) привертають велику увагу наукового психологічного співтовариства. Існує декілька тлумачень емоційного інтелекту: як емоційно-інтелектуальні здібності [5, с. 90]; як емоційної компетентності [6, с. 56]; як сукупності некогнітивних умінь і навичок, що впливають на здатність індивіда успішно впоратися з вимогами оточення, тобто адаптацію [1, с. 20]; як прояв емоційної розумності, що виявляється в умінні контролювати свої емоції та здатності налаштувати себе на активну діяльність у разі виникнення емоціогенних ситуацій; як інтегративну динамічну рису особистості [9] тощо. Аналіз наукової літератури дає змогу виділити складові компоненти емоційного інтелекту: самосвідомість (усвідомлення людиною свого суспільного статусу та своїх життєво важливих потреб), самоконтроль (усвідомлення й оцінювання суб'єктом своїх дій, психічних процесів і станів), емпатію (розуміння емоційного стану, проникнення-співчуття в переживання іншої людини), навички відносин (дії, які сформовані шляхом повторення, що характеризуються високим рівнем засвоєння), мотивацію (спонукання, які визивають активність організму та особистості загалом і визначають їі направленість) [2, с. 29].

На основі власного емпіричного дослідження Е. Носенко та Н. Коврига виділили й описали ієрархічну структуру емоційного інтелекту. На їхню думку, існують три рівні сформованості цього виду інтелекту: найнижчий рівень (здійснення емоційного реагування за механізмом умовного рефлексу; низький рівень самоусвідомлення; переважання зовнішніх компонентів над внутрішніми); середній рівень (спілкування на основі уявлень, мислення; перевага внутрішніх компонентів над зовнішніми; високий рівень самоконтролю; позитивне ставлення до себе); найвищий рівень (високий рівень розвитку внутрішнього світу людини; настанови щодо альтернативних форм поведінки в різних ситуаціях; гармонійне співвідношення внутрішніх і зовнішніх факторів; внутрішній локус контролю) [9]. Виділимо погляди вітчизняних учених також і на основні аспекти професійного самовизначення: 
1. Професійне самовизначення - це вибіркове ставлення індивіда до світу професій загалом і до конкретної вибраної професії [4].

2. Ядром професійного самовизначення є усвідомлений вибір професії з урахуванням своїх особливостей і можливостей, вимог професійної діяльності й соціально-економічних умов [10].

3. Професійне самовизначення здійснюється впродовж усього професійного життя: особистість постійно рефлексує, переосмислює своє професійне буття й самостверджується в професії [7].

4. Актуалізація професійного самовизначення особистості ініціюється різного роду подіями, такими як закінчення загальноосвітньоїшколи, професійногонавчальногозакладу, підвищення кваліфікації, зміна місця проживання, атестація, звільнення з роботи тощо [8]

5. Професійне самовизначення є важливою характеристикою соціально-психологічної зрілості особистості, її потреби в самореалізації й самоактуалізації [3, с. 45].

Визначені теоретичні підходи покладено в основу експериментального вивчення ролі емоційного інтелекту в професійному самовизначенні старшокласників, реалізоване нами з учнями 10-11 класів. Загальна кількість досліджуваних - 93 особи (дівчата і хлопці) віком від 15 до 17 років. Дослідження проводилося в груповій формі, на стандартизованих бланках, зі стандартними інструкціями. Під час проведення дослідження створені однакові умови, що впливають на результати тестування: уміст тестового матеріалу; складність питань; час, що відводиться на відповіді. Показниками для вибору методик були ї відповідність критеріям надійності й валідності, віковим особливостям досліджуваних, адекватність.

Методика професійного самовизначення Дж. Голанда дала нам змогу визначити ступінь зв'язку типу особистості зі сферою професійної діяльності, до якої в неї $є$ нахили. Вона складається з 43 пар професій, за допомогою яких визначається шість типів професійного

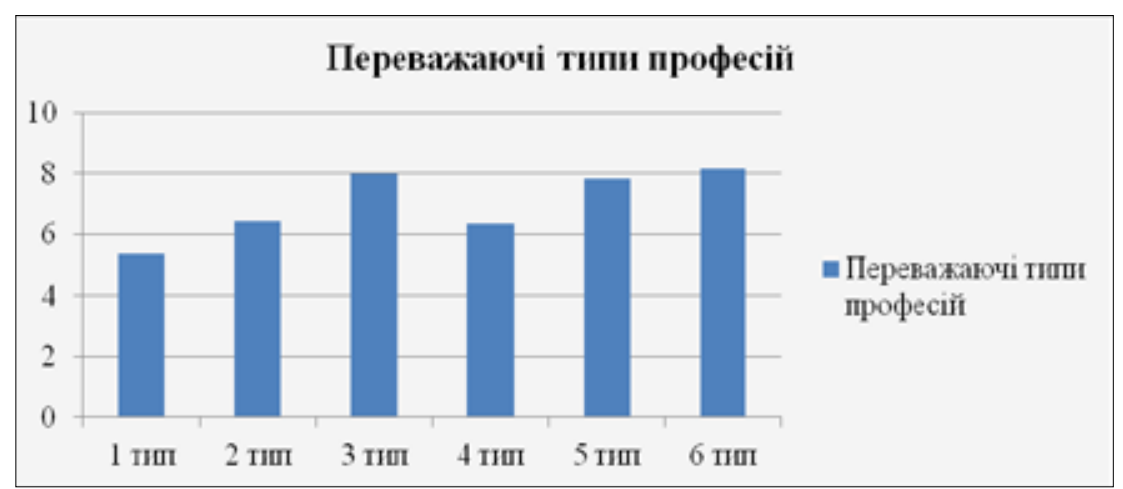

Рис. 1. Кількісні показники переважаючих типів професій за вибіркою (узагальнені результати) спрямування. Нижче в таблиці 1 нами представлено усереднені показники.

Для більш детального аналізу подамо усереднені показники переважаючих типів професій за вибіркою (рис. 1).

Отже, згідно з даними таблиці 1, нами встановлено, що більшості учнів притаманні професії соціального й артистичного типів. Особливо соціальний тип професій переважає в 11-му класі. Для 10-го класу більш характерний артистичний тип професійного самоспрямування. Це вказує на відсутність чіткого вибору направленості подальшого працевлаштування.

Для визначення рівня розвиненості емоційного інтелекту старшокласників ми обрали опитувальник емоційного інтелекту «ЕMIH» Д.В. Люсіна. Одна з його переваг у тому, що, крім п'яти субшкал і чотирьох шкал загального порядку, він також має загальну шкалу результатів. За цією методикою ми отримали середні бали за вибіркою, наведені в таблиці 2.

Отже, згідно з таблицею 2, надамо більш детальний кількісний і якісний аналіз отриманих показників. За шкалою МП (розуміння своїх емоцій) ми отримали середній бал 24,12. Це $€$ середньою нормою для цієї шкали (23-26). Цей бал також $є$ нормою в усіх групах досліджуваних. За шкалою МУ (управління чужими емоціями) ми отримали середній бал 19,65, що також $є$ середнім показником при нормі (18-21), як узагальнений, так і по групах. За шкалою ВП (розуміння своїх емоцій) ми отримали середній бал 16,49 при нормі (17-21), що є трохи нижчим за норму. Розглядаючи цей показник по групах, ми виявили, що в 11-му класі він низький. За шкалою ВУ (управління своїми емоціями) середній бал по вибірці становить 12,59, який також нижчий за норму (від 13 до 15), цей показник є низьким для всіх груп, це можна пояснити тим, що старшокласники не володіють навичками контролю своїх емоцій унаслідок відповідного їхньому віку етапу розвитку. За шкалою ВЄ (контроль експресії) ми отримали середній бал по вибірці 10,34, що знаходиться в межах норми (від 10 до 12), але в 11-му класі він знаходиться на кордоні між низьким і середнім значеннями (низьке значення 7-9, середнє - 10-12). Ці дані свідчать про низький рівень контролю експресії, що може зумовлюватися віковими рамками досліджуваних. За шкалою $\mathrm{MEI}$ (міжособистісній EI) ми отримали середній бал по вибірці - 43,60, що є середнім показником (40-46), цей показник залишається середнім для всіх досліджуваних нами груп. 
Показники значень по вибірці за методикою Дж. Голанда N = 93

\begin{tabular}{|l|c|c|c|}
\hline \multicolumn{1}{|c|}{ Назва шкал } & Загальна & $\mathbf{1 0}$ клас & $\mathbf{1 1}$ клас \\
\hline Реалістичний тип & 5,3478 & 5,0938 & 5,6842 \\
\hline Інтелектуальний тип & 6,4130 & 6,5000 & 5,4737 \\
\hline Соціальний тип & 8,0000 & 8,0312 & 9,1053 \\
\hline Конвенційний тип & 6,3478 & 6,6250 & 5,9474 \\
\hline Підприємницький тип & 7,8261 & 7,5938 & 8,0000 \\
\hline Артистичний тип & 8,1304 & 8,5625 & 8,7368 \\
\hline
\end{tabular}

Кількісні показники за методикою «ЕМІН" Д.В. Люсіна N = 93

\begin{tabular}{|c|c|c|c|}
\hline Назва шкал & Загальна & 10 клас & 11 клас \\
\hline МП (розуміння чужих емоцій) & 24,12 & 25,19 & 23,47 \\
\hline МУ (управління чужими емоціями ) & 19,65 & 20,47 & 18,79 \\
\hline ВП (розуміння своїх емоцій) & 16,49 & 16,31 & 14,68 \\
\hline ВУ (управління своїми емоціями ) & 12,59 & 12,72 & 11,21 \\
\hline ВЕ (контроль експресії) & 10,34 & 10,72 & 9,11 \\
\hline MEI (міжособистісній емоційний інтелект) & 43,60 & 45,50 & 41,68 \\
\hline ВЕІ (внутрішньоособистісний емоційний інтелект) & 39,82 & 40,38 & 36,05 \\
\hline ПЕ (розуміння емоцій) & 40,33 & 41,31 & 37,63 \\
\hline УЕ (управління емоціями ) & 43,11 & 44,56 & 40,63 \\
\hline Загальний бал & 83,81 & 86,38 & 78,26 \\
\hline
\end{tabular}

Кількісні показники значень по вибірці за методикою Н. Холла $\mathbf{N}=93$

Таблиця 3

\begin{tabular}{|l|c|c|c|}
\hline \multicolumn{1}{|c|}{ Назва шкал } & Загальна & $\mathbf{1 0}$ клас & $\mathbf{1 1}$ клас \\
\hline Емоційна обізнаність & 7,75 & 8,34 & 10 \\
\hline Управління своїми емоціями & 0,44 & 0,84 & $-0,31$ \\
\hline Самомотивація & 6,3 & 6,78 & 6,84 \\
\hline Емпатія & 7,59 & 9,84 & 7,68 \\
\hline Розпізнання емоцій інших людей & 7,09 & 8,59 & 6,63 \\
\hline
\end{tabular}

За шкалою BEI (внутрішньо особистісний ЕI) ми отримали середній бал по групі 39,82 при нормі (39-47). В 11 класі цей показник також нижчий за норму і становить 36,05 . За шкалою ПЕ (розуміння емоцій) виявлено середній бал по вибірці 40,33, що є середнім результатом при нормі (40-47), в 11 класі цей показник становить 37,63 . За шкалою УЕ (управління емоціями) середній результат становить 43,11, що входить у розділ норми (40-47). Загальна шкала OEI становить 83,81, що також $€$ нормою при середніх значеннях (79-92). Для більш детального вивчення рівня емоційного інтелекту старшокласників нами застосовано методику емоційного інтелекту Н. Холла. Вона відрізняється від попередньої методики наявністю шкал «Емпатія» та «Самомотивація», які вважаються особистісними, і шкалою «Емоційна обізна- ність», що вказує на те, наскільки досліджувані мають уявлення про емоції. Отримані результати презентовано в таблиці 3.

Розглядаючи детальніше результати (таблицю 3), можемо зазначити, що в 10-му $(8,34)$ та 11-му $(10,0)$ класах показники входять у рамки норми. Надамо зазначені результати у вигляді рис. 2.

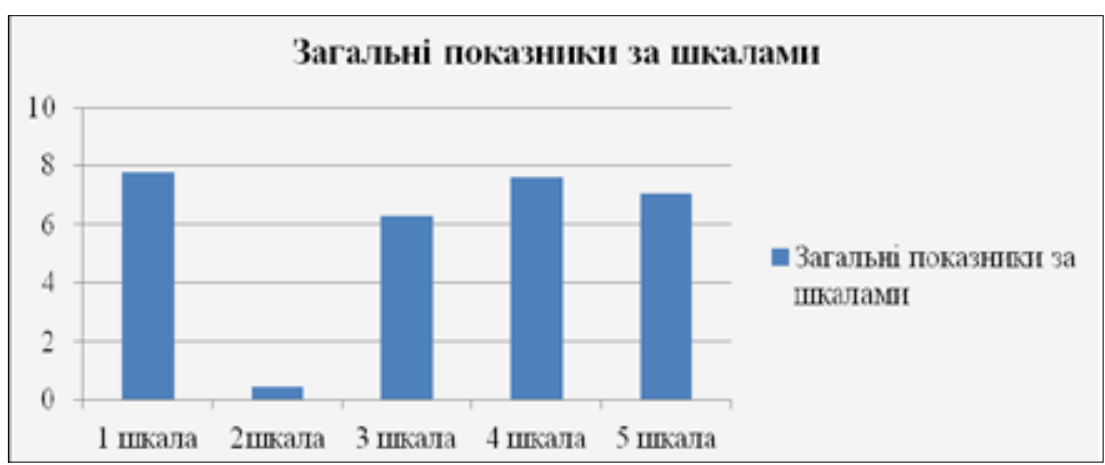

Рис. 2. Кількісні показники значень по вибірці за методикою Н. Холла 
За шкалою «Управління своїми емоціями» середній показник становить 0,44 бала. Він $€$ низький для всієї вибірки. Це пояснюється віковими особливостями розвитку старшокласників. Показники шкали самомотивації також досить низькі. Загальний середній показник становить 6,3 (7 і нижче - низький), він трохи нижчий за норму для кожної з досліджуваних груп. За шкалою емпатії загальний показник становить 7,59 бала. Він знаходиться на межі між середнім і низьким показниками. Під час детальнішого аналізу цього показника ми бачимо, що в 10-му класі бал за шкалою емпатії становить 9,84 та є нормою. у 11-му класі бал за шкалою емпатії становить 7,68 і знаходиться на межі між середнім і низьким показниками. Загальний показник за шкалою розпізнання емоцій інших людей також знаходиться на межі між середнім і низьким показниками, він становить 7,09 бала. В 11-му $(6,63)$ класі цей показник низький, а от у 10-му класі він середній $(8,59)$.

Висновки 3 проведеного дослідження. Отже, емоційний інтелект являє собою двокомпонентний конструкт, який складається з внутрішньоособистісного (здатність до розуміння власних емоцій та управління власними емоціями) і міжособистісного (здатність до розуміння емоцій інших та управління емоціями інших) компонентів. Роль емоційного інтелекту в професійному самовизначенні полягає в умінні визначити свої емоції, здатності керувати ними так, щоб досягти поставленої мети. За результатами емпіричного дослідження показників емоційного інтелекту старшокласників установлено, що в більшості досліджуваних переважає низький рівень емоційного інтелекту. Аналіз результатів емпіричного дослідження показав, що найменш вираженою в досліджуваних $€$ здатність до управління як власними емоційним станом, так й емоціями інших людей. За результатами дослідження нами встановлено, що досліджувані із соціальною направленістю професійного самовизначення дійсно мають високий рівень внутрішньоособистісного емоційного інтелекту. Особливо можна виділити схильність старшокласників соціального типу професійного самовизначення до розпізнання емоцій інших людей. Також ми визначили, що досліджувані з реалістичним типом професійного самовизначення мають низькі показники емпатії. Досліджувані 3 вибором підприємницького типу професійного самовизначення мають низькі показники за шкалою управління своїми емоціями.

Перспективи подальших досліджень убачаємо у вивченні характеру зв'язку між складниками емоційного інтелекту і стабільністю статусу особистості в групі, у системі комунікативних, інтерактивних і перцептивних впливів.

\section{ЛITЕРАТУРA:}

1. Березюк Г. Емоційний інтелект як детермінанта внутрішньої свободи особистості. Психологічні cmудії Львівського університету. 2007. С. 20-23.

2. Головань Т. Необхідність розвитку емоційного інтелекту EQ. Світ виховання. 2010. № 3. С. 29-30.

3. Гинзбург М.Р. Личностное самоопределение как психологическая проблема. Вопросы психологии. 1998. № 2. С. 45-56.

4. Гоулман Д. Эмоциональный интеллект / пер. с англ. А.П. Исаевой. Москва : АСТ : АСТ МОСКВА ; Владимир : ВКТ, 2010. 478 с.

5. Деревянко С.П. Ситуативные аспекты актуализации эмоционального интеллекта. Социальный и змоциональный интеллект: От процессов к измерениям / под ред. Д.В. Люсина, Д.В. Ушакова. Москва : Институт психологии РАН, 2009. С. 90-113.

6. Зарицька В.В. Емоційний інтелект: актуальність проблеми. Вісник ХНПУ ім. Сковороди. Серія «Психологія». Харків : ХНПУ, 2008. Вип. 24. С. 56-65.

7. Климов Е.А. Психологія професійного самовизначення : навчальний посібник для вузів. Ростовна-Дону : Фенікс, 1996. 512 с.

8. Мудрик А.В. Современный старшеклассник: проблемы самоопределения. Москва : Знание, 1977. 238 c.

9. Носенко Е.Л., Коврига Н.В. Емоційний інтелект: концептуалізація феномену, основні фрункції. Київ : Вища шк., 2003. 126 с.

10. Пряжніков М. Особиста профресійна перспектива. Психолог. 2004. № 16. 342 с. 